\title{
Superstition and Cultural Diversity-Case Study: Isfahan Province, Iran
}

\author{
Kamran Rabiei \\ PhD candidate in Sociology, University of Isfahan \\ E-Mail: rabieik@@yahoo.com \\ Vahid Ghasemi \\ Associate Professor in Sociology, University of Isfahan \\ E-Mail: v.ghasemi@ltr.ui.ac.ir \\ Habib-Reza Arzani \\ Assistant Professor in Islamic Theology, \\ The Academy of Islamic and Science of Qom \\ E-Mail: Habibb_01@yahoo.com
}

Doi: 10.5901/mjss.2013.v4n4p73

\begin{abstract}
Studying different cultures clarifies that general values and attitudes are closely related to the other aspects of individuals' life. Economical conditions, historical experiments, geographical environment, etc are among the factors forming individuals' beliefs, and consequently any alteration in any of these factors changes the individuals' beliefs accordingly. Superstition is an ingredient of the public beliefs detectable in almost all cultures; though its definition has been exposed to alterations through the time. The current study aims at collecting and categorizing different superstitions in Isfahan province, Iran. All 15 years old and above are considered as the population for the current study. The total sample size consists of 6192 individuals, selected based on three variables of age, sex, and residential area. The current study enjoys the conventional approach, with survey to study and recognize the superstitions. Open questions are asked in face-to-face interviews. Every individual is asked to answer the questions after contemplating about his/ her superstitious beliefs and those of his/ her parents and residential subprovince as well. The results indicate that all superstitions are in accordance with economical conditions, and value alterations in Iranians beliefs.
\end{abstract}

Keywords: Superstition; Cultural Diversity; Conventional approach; Isfahan Province; Iran;

\section{Introduction: superstition in different cultures}

The will to comprehend and discover the world, in order to know and control it, is the foundation of the epistemology and cosmology of the primitives. However the knowledge and understanding of humankind was bound to time and place and also was influenced with their individual and collective experience. Therefore in different societies and cultures there has been a similar intention to understand the world, however, along the history of human kind the answers to the very same question were of different and varied nature.

Superstitions as a social construction just like the other concepts, no matter either in its evidence or its meaning sphere could differ from culture to culture. Consequently defining the term 'superstition' if not impossible is a challenging wish to fulfill. Another difficulty of defining superstition originates from its overlap with the other domains of knowledge such as religion and science. Hence, numerous definitions are found for the entry of superstition in dictionaries, accordingly this plurality could be an indication of different comprehensions of the concept namely superstition.

Etymologically the term superstition has been related to supernatural (Becker, 1975). Oxford dictionary defines superstition as "excessively credulous belief in and reverence for the supernatural" and " a widely held but irrational belief in supernatural influences, especially as leading to good or bad luck, or a practice based on such a belief" (Oxford Dictionary, 2012). According to this definition, superstition works beyond the boundaries of causal relations and physical world.

Webster's Third new international dictionary- unabridged (1986) defines superstition as follows: 
"a belief or practice resulting from ignorance, fear of the unknown, trust in magic or chance, or a false conception of causation; an irrational abject attitude of mind toward the supernatural, nature, or God resulting from superstition; a notion maintained despite evidence to the contrary"(pp. 2296).

In encyclopedia of Britannica (2008), the entry of superstition is defined as:

"A belief, half-belief, or practice for which there appears to be no rational substance. Those who use the term imply that they have certain knowledge or superior evidence for their own scientific, philosophical, or religious convictions. An ambiguous word, it probably cannot be used except subjectively. With this qualification in mind, superstitions may be classified roughly as religious, cultural, and personal".

As clarified by definitions provided in English dictionaries and encyclopedias superstition is defined with the help of the terms: "irrational", "non-scientific", "fear", "ambiguity", and "ignorance" etc, thus introducing superstition as a wrong belief and knowledge.

In Arabic dictionaries, superstition is defined as follows: "an appealing and fabricated word" (Kitab al-Ayn, 1988, vol.4: 252), "invalid word" (Aqrab al-mawarid, 1992, vol.1: 268), "made up words and falsehood for gatherings" (Taj Al 'Arus, Vol. 12: 162), and "myth and spurious tale or irrational beliefs and activities" (Majma' Al-Bahrain, 2001). Persian dictionaries define superstition as an invalid absurd narration, falsehood, myth and legend (Amid, 2010: 478; Moein, 1999: 1409). Thus, as it is clear in non-western dictionaries either Arabic or Persian, superstition stands against "wisdom", "accuracy", and "reality".

Jahoda (1968) in his classification of superstitions differentiates between "causal superstitions" and "coincidental superstitions". Causal superstition is a part of a conscious belief in a relationship between two events. This kind of superstition is found in Skinner's experiment (1948) on pigeons; in the experiment, the pigeons believed that there was a relation between jerking their heads and food appearing. Coincidental superstitions enjoy of more ambiguity in causality correlation between a behavior and an outcome. Examples of this kind of superstition could be that of ancient Romans about the relation between natural phenomena and gods, or the reasons among different nations and cultures for the origins of natural disasters.

Prevalent culture, generally, affects the individual responses to environmental stimulus. Totality of culture, respectively, is influenced by environmental conditions, historical experiences, geographical location, kind and volume of cultural and commercial exchanges, technological advances, and the stage of industrial development to name some. In a country such as Iran, similarly, popular beliefs are in accordance with the other cultural beliefs and the structure of society, consequently superstitions are not exception to the rule.

The current research aims at finding, collecting and analyzing superstitions in Isfahan province in Iran. Further, it will be discussed that how the superstitions, found throughout the Isfahan province apart from their diversity and numerousness, are bound to the local and regional traits; also it will be discussed that how the individual appreciation of superstitious rituals have been changed under the processes of modernization and globalization.

In order to study superstitions one can apply scientific, philosophical, intra-religious, and conventional approaches. In scientific approach any belief which is not observable, experiential and experimental could be considered as superstition. In philosophic approach, rational and logical argumentation is the criterion for differentiation and discrimination between superstition and non-superstition; intra-religious approach considers the religious logic, prophet's attitudes, and elite clergies' opinions as the criterion for distinguishing between superstition and non-superstition. However, in conventional approach which is closer to the sociological and anthropological approach it is agreed that the difference between superstition and non-superstition is the conventional wisdom. Conventional approach, indeed, does not aim to apprehend and recognize the truth; rather it aims to examine the individual imagination and apprehension, existing social contracts among individuals and also to study what is named as superstition among people. Undoubtedly, common conception is changing over the time according to socio-economic changes, which could be a subject for sociological and anthropological studies. The main approach in the current study would be the conventional approach; and aims at studying the understanding of individuals of their own superstitious beliefs, that of their parents, and that of their residential sub-province.

\section{Nature of Superstitions: Causes and Mechanisms}

About the nature and reasons behind the creation of the superstitions there have been a lot of arguments. Anthropology, sociology, and psychology, among all, have dealt with the subject of the human tendency towards the superstition within their perspectives from different viewpoints. 
Studying different cultures clarifies that superstition is a global issue not bound to a specific era and society. since superstition has its own functions in different societies, and human besides his/her rational aspect enjoy an irrational and emotional one, therefore the superstitious beliefs continue to exist in human societies. (Beck \&Forstmeier, 2007, Vyse, 1997). Under the influence of enlightenment and secular movements in eighteenth and nineteenth centuries superstition was considered beside the religious beliefs. now the relationship between the superstition and religion is open to dispute (Rudski, 2004, Jahoda, 1969, Vyse, 1997).

Secular superstitions are now under debate and most of popular beliefs are categorized under superstitions. (Torgler, 2007, Weiner, 2008).in the past the subjects of science and non-science were not understood as distinct knowledge systems. Believing in magic, astronomy, alchemy was not considered as superstitions and non-scientific subjects (Hansen, 1986, Perkins, 1996, Perkins, 2000). it is only in modern era that knowledge systems are differentiated from each other, and under the influence of $19^{\text {th }}$ century Positivism what is not observable and experimental is considered beyond the boundaries of science and even sometimes are labeled as superstition.

McCartney (1952) seeks the roots of superstition in the fears that human experience collectively or individually. the fear from the incomprehensible, inexplicable, unpredictable, and destructive natural forces representing themselves as superstitious beliefs and rituals. Recent studies prove that most of disappointing notions in folk culture are related to the outer threats. Individuals are stimulated to accept irrational and superstitious beliefs when they lose their sense of control over events and outcomes or even when the conditions grow dubious (Blum \& Blum, 1974; Dunleavy, 1989; Gmelch \& Felson, 1980; Case et al., 2004; Hunt \& Short, 2006). Applying all these superstitions individuals make their surrounding worlds more meaningful, predictable, and controllable (Case et al., 2004; Keinan, 1994).

About the unstable and doubtful influence of outer impacts on the creation and spread of superstitious beliefs Malinowski's example (1948) is very noticeable. He observed that when Trobriand Islanders were going to fishing in open seas which contain danger and uncertainty used magic while when they were going to fishing in safe lagoons there were no trace of magic.

In most anthropological and sociological texts "magic" is considered as an equal to superstition. Magic, however, exists in all cultures and is related to uncertainties, instabilities, and threatening conditions directed into specific ritual practices (Douglas, 1966).

Superstitious beliefs are the result of a particular attitude toward the relationship between human and existence which is sometimes mentioned as "magical thinking". According to this point of view mind can influence the physical world, and without any causal explanation affect the events (Pronin et. al., 2006). This thinking manner results in superstitious rituals. People engaged in such rituals think that practicing some activities and behaviors cause a favorable outcome, although, they can never raise any causal relationship between them (Case et al., 2004; Vyse, 1997; Jarvis, 1980; Pronin et al, 2006; Womack, 1992; Becker, 1975; Campbell, 1996).

Prior to modern age, magic was prevalent in societies compared to today, because the natural environment was such too threatening and mystical and the human knowledge about natural forces was so limited (Bauer, 1966).

Through superstitious beliefs or magical rituals, individuals follow procedures that increase their sense of control over threat resources and decrease their experienced stress (Keinan, 1994: 8; Forst et al., 1993: 423). This also may cause them illusion of control (Langer, 1975). In such a situation, they come to believe that some of their behavior has given birth to a result which is not in their domain of control and acts (Rudski \& Edwards, 2007; Rudski et al., 1999)

From a specific perspective, superstition could be understood as a method of mental preparation (Becker, 1975; Jarvis, 1980; Neil, 1982; Womack, 1992), which may cause the individual to have a false sense of having control over outer conditions and reduces his tensions and anxieties (Taylor, 1983). Some researchers have mentioned the negative impacts of believing in superstitions on personal performance (Tobacyk \& Shrader, 1991; Bleak \& Fredrik, 1998).

All in all, one can say that outer environmental conditions and existing security degree has a profound effect on the creation, diffusion, and duration of the superstitions. Superstitions are prevalent in conditions in which the uncertainty, lack of confidence, insecurity, fear and threat, stress and anxiety are in abundance. Yet, whenever the events are explicable and interpretable, environment is more transparent, and conditions are less ambiguous individual tend lesser towards the superstitious beliefs and explanations (Becker, 1975; Barsky et al. 2002; Hamerman, 2010: 8; Laurin et al., 2008; McGregor, 2006 a \& b; McGregor, et al., 2001; McGregor, et al., 2008).

It is worth mentioning that although superstitious beliefs are non-scientific, one may find in them an internal coherence, which gives them a pragmatic nature against milieu and outer conditions (Womack, 1992). Most of superstitions are inclined towards problem solving, which may be because of human's need to understand the existence, nature, and outer forces. Superstitious beliefs are closely related to the other values and beliefs of every ethnic group and human community. A thorough analysis of superstitions clarifies their role in organizing social and individual life in any given society. 
The question arising here is "which mechanisms cause the creation of the superstitious beliefs?". Some scholars mention to the mechanisms such as "synchronicity", "coincidence", and "contiguity" (Pronin, et al., 2006; Vyse, 1997; Bernardin, 2004; Langer \& Roth, 1975).

When a behavior or conduct is committed and after that, there happens a specific outcome, human mind is inclined toward relating them to each other and make an induction. This synchronicity gains importance for individuals when the outcome has fulfilled one of their specific needs or requirements. Repeating this synchronicity amplifies the belief, although one may not find any causal relationship between them. Understanding this synchronicity and coincidence between behavior and outcome usually requires a contiguity of space, place, and time.

Skinner (1948) in his well known experiment on pigeons and food, Wagner and Morris (1987) it their experiment on children and dulls, and Ono (1987) in his experiment on students and light signals, have tried to show how the synchronicity mechanism creates the superstitious beliefs.

Different variables affect tendency toward superstition. Related researches have indicated the effect of different variables on individuals' tendency toward accepting superstitious beliefs. Emme (1940) by reviewing the findings of previous studies came to this conclusion that, believing in superstitions decreases by the increasing of age and education, and according to his review women are more superstitious than men, his review is also proved by later studies (See Blum \& Blum, 1974; Tobacyk \& Milford, 1983; Zebb \& Moor, 2003; Griffiths \& Bingham, 2005;).

Regarding the education, Otis and Alcock (1982) have come to conclusion that by increasing the educational level the acceptance of superstition decreases and skepticism increases. Peltzer's study (2002) approves their study; additionally about the variable of age contrary to Emme's findings, Griffiths and Bingham's study (2005) has led to a different result in which the older a person grows the more superstitious he becomes.

Studies carried on the relationship between the religiosity and believing in superstitions has not led to unanimous findings. While Buhrman and Zaugg (1981) in their study have found a direct relationship between level of religiosity and believing in superstition, Bleak \&Fredrieck (1998) have come to the end that there is no relationship between them. Another study carried on the same subject indicates that religious and non-religious people enjoy almost equal level of believing in superstitions, however religious people have more tendencies toward the metaphysical beliefs (Gallup \& Newport, 1990).

\section{Research Method}

As mentioned before, the main goal of this study is to collect and analyze the superstitions available in Isfahan province, Iran. The best way to study superstitions and know the mentality of individuals is phenomenological and ethnographic interviews. While this method of studying is usually recommended for studies carried on limited samples and small groups, for the studies carried on large scale groups and collecting considerable amount of data it is recommended to use the survey method. Current study aims at studying the mentality of individuals and collecting data in a large quantity, so it enjoys both phenomenological method and survey (qualitative and quantitative methods) respectively. In order to fulfill this goal a survey with open questions was administered.

All residents of 15 years and above in Isfahan province were as the population for the current study. Regarding the population, Isfahan is the third populated province of Iran (Statistical Center of Iran, 2006). The total sample size of the current study consists of 6192 individuals, selected based on three variables of age, sex, and residential area according to the multistage quota sampling in 25 sub-province and urban areas. Open questions of questionnaire were asked in face-to-face interviews. Every individual was asked to answer the questions after contemplating about his/ her superstitious beliefs and those of his/ her parents and residential sub-province as well. Mentioned cases were initially encoded then categorized and ultimately fed into SPSS-16 to be analyzed.

\section{Findings}

To understand and recognize the mentality of residents in Isfahan Province, they were first given two groups of question items to show their agreement or disagreement. For scholars of the social sciences, five items indicate popular superstitions in Iranian society. Also three items were related to respondents' fatalistic beliefs (items of 6 to 8 in table 1).

Based on the results in table 1, acceptance of various beliefs in Iranian society is influenced by different reasons. Only 21.9 percent agreed with the belief "tying grass is said to be a good omen for singles to find their partner" and 79.2 percent agreed with "setting wild rue on fire removes whammy". the research findings revealed that people of Isfahan, or Iranian society as a whole, are rather fatalist as opposed to believing in superstitious ideas. For example, 60.8 percent of the respondents believed "everybody's destiny is already predetermined" and 75.5 percent believed "some individuals 
are lucky". 35.8 percent of them believed that "we cannot change our fate" which is also a high ratio. To sociologists' view, this is an indication that in society lower chances of life exist and social mobility and improved economic well-being is difficult to obtain. It must be mentioned that fatalistic beliefs, specially having pre-determined fate does not seem negative in Iran and is understood in relation to God's willpower and fate.

Table1: Respondents' approaches about some popular beliefs

\begin{tabular}{|c|c|c|c|c|c|c|c|c|c|c|c|c|c|c|}
\hline \multirow[t]{3}{*}{ row } & \multirow[t]{3}{*}{ items } & \multicolumn{3}{|c|}{$\begin{array}{c}\text { Percentage of } \\
\text { agreement }\end{array}$} & \multicolumn{10}{|c|}{ The relationship between belief to superstitions and different variables } \\
\hline & & \multirow[t]{2}{*}{ agree } & \multirow[t]{2}{*}{$\begin{array}{c}\text { disagr } \\
\text { ee }\end{array}$} & \multirow[t]{2}{*}{$\begin{array}{l}\text { valid } \\
\text { cases }\end{array}$} & \multicolumn{2}{|c|}{ sex } & \multicolumn{2}{|c|}{ age } & \multicolumn{2}{|c|}{ education } & \multicolumn{2}{|c|}{ religiosity } & \multicolumn{2}{|c|}{$\begin{array}{l}\text { monthly } \\
\text { household } \\
\text { expenses }\end{array}$} \\
\hline & & & & & sig & v & sig & v & sig & v & sig & v & sig & v \\
\hline 1 & $\begin{array}{l}\text { I believe in the } \\
\text { fortunetelling of } \\
\text { the publications }\end{array}$ & 18.6 & 81.4 & 6163 & 0.000 & 0.089 & 0.000 & 0.132 & 0.000 & 0.065 & 0.000 & 0.090 & 0.206 & 0.023 \\
\hline 2 & $\begin{array}{l}\text { tying grass is } \\
\text { said to be a } \\
\text { good omen for } \\
\text { single people }\end{array}$ & 21.9 & 78.1 & 6140 & 0.000 & 0.102 & 0.000 & 0.163 & 0.000 & 0.304 & 0.001 & 0.054 & 0.000 & 0.127 \\
\hline 3 & $\begin{array}{l}\text { number } 13 \text { is } \\
\text { unlucky }\end{array}$ & 22.8 & 77.2 & 6164 & 0.000 & 0.055 & 0.000 & 0.162 & 0.000 & 0.308 & 0.001 & 0.054 & 0.000 & 0.141 \\
\hline 4 & $\begin{array}{l}\text { doing some } \\
\text { works in some } \\
\text { days is ominous } \\
\text { and has bad } \\
\text { luck }\end{array}$ & 42.6 & 57.4 & 6148 & 0.001 & 0.043 & 0.000 & 0.092 & 0.000 & 0.231 & 0.000 & 0.068 & 0.000 & 0.131 \\
\hline 5 & $\begin{array}{l}\text { the smoke of } \\
\text { wild rue } \\
\text { removes } \\
\text { whammy }\end{array}$ & 79.2 & 20.5 & 6165 & 0.000 & 0.136 & 0.267 & 0.032 & 0.000 & 0.160 & 0.000 & 0.132 & 0.000 & 0.144 \\
\hline 6 & $\begin{array}{l}\text { we can not } \\
\text { change our fate }\end{array}$ & 35.8 & 64.2 & 6164 & 0.000 & 0.096 & 0.000 & 0.183 & 0.000 & 0.279 & 0.000 & 0.061 & 0.000 & 0.120 \\
\hline 7 & $\begin{array}{l}\text { ever y body' } \\
\text { destiny is } \\
\text { previously } \\
\text { determined }\end{array}$ & 60.8 & 39.2 & 6153 & 0.000 & 0.104 & 0.000 & 0.136 & 0.000 & 0.248 & 0.000 & 0.082 & 0.000 & 0.121 \\
\hline 8 & $\begin{array}{l}\text { some people are } \\
\text { inherently lucky }\end{array}$ & 75.4 & 24.6 & 6167 & 0.001 & 0.041 & 0.271 & 0.032 & 0.000 & 0.127 & 0.001 & 0.057 & 0.000 & 0.087 \\
\hline
\end{tabular}

Based on the findings of table 1 , there are significant relationships among the following variables: tendency to "superstitious beliefs", "fatalistic beliefs" and "sex', "age", "education", "religiosity", and "monthly household expenses". As a whole, it seems that women believe in superstition more than men. The older they become, the more their tendency towards superstitious and fatalistic beliefs. Also, there is a positive relationship between high religiosity and belief in superstition. Although the results reveal that the severity of the relationship in religiosity variable is not high, the cost of living shows that lower strata in society hold more superstitious and fatalistic beliefs, except " they do not study fortunetelling publications," which is a hobby for high-level citizens "Education" variable has a negative effect on superstitious beliefs. The findings show that this variable is more effective than other variables. In fact, it can be said that in Iranian society, the most effective factor on decrease of beliefs in superstitious ideas is higher education.

The respondents were asked whether or not they know of any belief without reason or any logical reasoning which can be said to be superstitious in itself, among their parents and their sub-province of residence. It is seen in the responses that the more they move towards their parents and sub-province, the more their judgment will become negative. As it is seen in table 2, 48.86 percent of the respondents announced that they have superstitious beliefs, whereas 69.64 percent declared they know some superstitious beliefs among their parents. This ratio is more for the sub-province(87.24 percent). Since individuals have more clear and positive judgments about themselves than others, this difference is very obvious. It is important to notice that superstitious beliefs for respondents are not necessarily an annoying problem. In fact, although respondents resist against the label of superstitious, they accept their superstitious beliefs. Also, the ratio of 87.24 percent of respondents' beliefs in superstition in the sub-province bespeaks of an emotional distance between individual and society. 
Table 2: Respondents' view about superstitious beliefs of self, parents and residential sub-province

\begin{tabular}{|l|l|l|l|l|l|}
\hline \multirow{2}{*}{$\begin{array}{l}\text { superstitious } \\
\text { beliefs }\end{array}$} & no & yes & \multirow{2}{*}{ valid cases } \\
\cline { 2 - 5 } & frequency & percentage & frequency & percentage & \\
\hline respondents & 2527 & 51.14 & 2414 & 48.86 & 4941 \\
\hline parents & 1582 & 30.36 & 3629 & 69.64 & 5211 \\
\hline Sub-province & 997 & 12.76 & 6812 & 87.24 & 7809 \\
\hline
\end{tabular}

It can be observed that individuals and society each hold different attitudes with regard to superstitions through superstitious beliefs of respondents about themselves, their parents and the sub-province. it is as follows: 3573 for the self, 5839 for parents and 7880 for the residential sub-province. These data was codified and then categorized. the results are presented in table 3.

In relation to respondents' and parents' beliefs, apart from the ratios and percentages, the first three items are classified in the personal level whereas when the individual thinks about the superstitious beliefs in the sub-province , $\mathrm{s} / \mathrm{he}$ considers group ceremonies and common values rather than personal beliefs. It is interesting that 22.4 percent of beliefs in the residential sub-province were just emotional reactions. In fact, the respondent believes in the superstitious beliefs in the sub-province but s/he cannot remember immediately and pretends that "it is not in my mind". It may be related to the weak outcomes of group unity caused by social changes in which most people believe in superstitious beliefs in their environment which is under its effect. This also presents a vague image of the society in which they live. It is noticeable that religious beliefs in a religious and traditional society are a factor in social unity and there are no challenges about it as is shown in tables 4.

Table 3: Basic issues about respondents' superstitious beliefs

\begin{tabular}{|c|c|c|c|c|c|c|c|c|c|}
\hline row & $\begin{array}{l}\text { personal } \\
\text { superstition }\end{array}$ & frequency & $\begin{array}{l}\text { perce } \\
\text { ntage }\end{array}$ & $\begin{array}{l}\text { parents' } \\
\text { superstition }\end{array}$ & frequency & $\begin{array}{l}\text { perce } \\
\text { ntage }\end{array}$ & $\begin{array}{l}\text { Sub-province } \\
\text { superstition }\end{array}$ & $\begin{array}{l}\text { frequ } \\
\text { ency }\end{array}$ & $\begin{array}{l}\text { perc } \\
\text { enta } \\
\text { ge }\end{array}$ \\
\hline 1 & body organs & 791 & 22.1 & $\begin{array}{l}\text { objects and } \\
\text { their } \\
\text { characteristics }\end{array}$ & 1004 & 17.2 & $\begin{array}{l}\text { respondents' } \\
\text { unawareness }\end{array}$ & 1765 & 22.4 \\
\hline 2 & $\begin{array}{l}\text { numbers, time } \\
\text { and day }\end{array}$ & 502 & 14.0 & $\begin{array}{l}\text { numbers, time } \\
\text { and day }\end{array}$ & 867 & 14.8 & $\begin{array}{l}\text { different } \\
\text { ceremonies }\end{array}$ & 1552 & 19.7 \\
\hline 3 & $\begin{array}{l}\text { objects and their } \\
\text { characteristics }\end{array}$ & 502 & 14.0 & body organs & 808 & 13.8 & religious beliefs & 754 & 9.6 \\
\hline 4 & religious beliefs & 472 & 13.2 & $\begin{array}{l}\text { belief in } \\
\text { unluckiness }\end{array}$ & 562 & 9.6 & $\begin{array}{l}\text { marriage } \\
\text { ceremonies }\end{array}$ & 693 & 8.8 \\
\hline 5 & magic \& omen & 196 & 5.5 & magic \&omen & 519 & 8.9 & magic \&omen & 686 & 8.7 \\
\hline 6 & guest & 148 & 4.1 & religious beliefs & 379 & 6.5 & $\begin{array}{l}\text { numbers, time } \\
\text { and day }\end{array}$ & 639 & 8.1 \\
\hline 7 & $\begin{array}{l}\text { ghost, jinni \& the } \\
\text { dead }\end{array}$ & 143 & 4.0 & guest & 254 & 4.4 & $\begin{array}{l}\text { objects and their } \\
\text { characteristics }\end{array}$ & 489 & 6.2 \\
\hline 8 & $\begin{array}{l}\text { animals and } \\
\text { birds }\end{array}$ & 127 & 3.6 & $\begin{array}{l}\text { animals and } \\
\text { birds }\end{array}$ & 193 & 3.3 & body organs & 340 & 4.3 \\
\hline 9 & $\begin{array}{l}\text { marriage \& } \\
\text { pregnancy } \\
\text { ceremonies }\end{array}$ & 114 & 3.2 & plants \&eats & 168 & 2.9 & $\begin{array}{l}\text { ghost, jinni \& the } \\
\text { dead }\end{array}$ & 244 & 3.1 \\
\hline 10 & belief in fortune & 101 & 2.8 & $\begin{array}{l}\text { marriage } \\
\text { ceremonies }\end{array}$ & 125 & 2.1 & $\begin{array}{l}\text { pregnancy \& } \\
\text { child-care }\end{array}$ & 166 & 2.1 \\
\hline 11 & $\begin{array}{l}\text { sleep \& falling } \\
\text { asleep }\end{array}$ & 45.0 & 1.3 & $\begin{array}{l}\text { sleep \& falling } \\
\text { asleep }\end{array}$ & 106 & 1.8 & guest & 99 & 1.3 \\
\hline 12 & trip & 34 & 1.0 & jinni \& ghost & 81 & 1.4 & animals and birds & 86 & 1.1 \\
\hline 13 & colors & 30 & .8 & trip & 73 & 1.3 & plants \&eats & 71 & .9 \\
\hline 14 & plants \& eats & 22 & .6 & colors & 63 & 1.1 & $\begin{array}{l}\text { sleep \& falling } \\
\text { asleep }\end{array}$ & 38 & .5 \\
\hline 15 & $\begin{array}{l}\text { belief in } \\
\text { unluckiness }\end{array}$ & 10 & .3 & $\begin{array}{l}\text { mourning \& the } \\
\text { dead }\end{array}$ & 61 & 1.0 & colors & 28 & .4 \\
\hline
\end{tabular}




\begin{tabular}{|l|l|l|l|l|l|l|l|l|l|}
\hline 16 & $\begin{array}{l}\text { belief in deed } \\
\text { retribution }\end{array}$ & 10 & .3 & $\begin{array}{l}\text { belief in } \\
\text { unluckiness }\end{array}$ & 42 & .7 & $\begin{array}{l}\text { belief in } \\
\text { unluckiness }\end{array}$ & 21 & .3 \\
\hline 17 & etc... & 326 & 1 & $\begin{array}{l}\text { pregnancy \& } \\
\text { child-care } \\
\text { ceremonies }\end{array}$ & 40 & .7 & trip & 19 & .2 \\
\hline 18 & total & 3573 & 100 & $\begin{array}{l}\text { belief in deed } \\
\text { retribution }\end{array}$ & 2 & .0 & $\begin{array}{l}\text { belief in } \\
\text { unluckiness }\end{array}$ & 10 & .1 \\
\hline 19 & & & & $\begin{array}{l}\text { special } \\
\text { ceremonies }\end{array}$ & 1 & .0 & $\begin{array}{l}\text { belief in deed } \\
\text { retribution }\end{array}$ & 2 & .0 \\
\hline 20 & & & & etc... & 491 & 5.5 & etc... & 178 & 2.3 \\
\hline 21 & & & & total & 5839 & 100 & total & 7880 & 100 \\
\hline
\end{tabular}

In relation with present beliefs in different levels, the important point is the variety of the beliefs both in numbers and in subjects. About 343 superstitious beliefs were gathered in which 527 are about parents and 427 about subprovince. These variety and excess in these beliefs are very interesting and considerable both from humanistic and sociological views. They can be observed in table 4 one by one and without any classifications. Since they were a lot, those about one percent or less are categorized in "etc." item.

Table 4: Superstitious beliefs of self, parents and popular superstitious beliefs in the sub-province from respondents' view

\begin{tabular}{|c|c|c|c|c|c|c|c|c|c|}
\hline row & individual & $\begin{array}{l}\text { Frequ } \\
\text { ency }\end{array}$ & $\begin{array}{c}\text { percent } \\
\text { age }\end{array}$ & parents & $\begin{array}{l}\text { Frequ } \\
\text { ency }\end{array}$ & $\begin{array}{c}\text { percen } \\
\text { tage }\end{array}$ & Sub-province & $\begin{array}{l}\text { Frequ } \\
\text { ency }\end{array}$ & $\begin{array}{c}\text { percent } \\
\text { age }\end{array}$ \\
\hline 1 & $\begin{array}{l}\text { sneezing is a sign of } \\
\text { patience }\end{array}$ & 375 & 10.4 & $\begin{array}{l}\text { the unluckiness of some } \\
\text { week days }\end{array}$ & 508 & 8.7 & $\begin{array}{l}\text { it exists but I do not } \\
\text { have mental alacrity }\end{array}$ & 838 & 12.2 \\
\hline 2 & $\begin{array}{l}\text { not necessity of doing } \\
\text { some issues in some } \\
\text { special days }\end{array}$ & 227 & 6.3 & $\begin{array}{l}\text { it exists but I don't } \\
\text { remember any thing }\end{array}$ & 428 & 7.3 & $\begin{array}{l}\text { fortunetelling, palmistry } \\
\text { \&augury }\end{array}$ & 403 & 5.9 \\
\hline 3 & $\begin{array}{l}\text { opening and closing } \\
\text { scissors is bad, it is } \\
\text { unlucky, it make quarrel }\end{array}$ & 77 & 2.1 & cutting the nails at night & 322 & 5.5 & $\begin{array}{l}\text { self-mutilation, to } \\
\text { flagellate with a chain \& } \\
\text { to strike with a sword }\end{array}$ & 370 & 5.4 \\
\hline 4 & belief in whammy & 200 & 5.5 & $\begin{array}{l}\text { opening and closing the } \\
\text { scissors /hitting two keys } \\
\text { make quarrel }\end{array}$ & 309 & 5.3 & $\begin{array}{l}\text { extremes in mourning } \\
\text { ceremonies, caravan, } \\
\text { homily \& commission }\end{array}$ & 335 & 4.9 \\
\hline 5 & the smoke of wild rue & 186 & 5.1 & $\begin{array}{l}\text { sneezing and being } \\
\text { patient }\end{array}$ & 308 & 5.2 & $\begin{array}{l}\text { praying(invocation)/ pray } \\
\text { writing }\end{array}$ & 272 & 4.0 \\
\hline 6 & $\begin{array}{l}\text { I can not remember but } \\
\text { I believe in superstition }\end{array}$ & 170 & 4.7 & $\begin{array}{l}\text { opening a praying book } \\
\text { to solve the problems }\end{array}$ & 209 & 3.6 & $\begin{array}{l}\text { being propitious or } \\
\text { inauspicious of some } \\
\text { works in special days }\end{array}$ & 256 & 3.7 \\
\hline 7 & $\begin{array}{l}\text { breaking eggs to } \\
\text { remove whammy }\end{array}$ & 129 & 3.6 & whammy & 191 & 3.3 & $\begin{array}{l}\text { present ceremonies in } \\
\text { the weddings/ tying/ to } \\
\text { be strict about dowry }\end{array}$ & 236 & 3.4 \\
\hline 8 & fortunetelling, \&augury & 108 & 3.0 & $\begin{array}{l}\text { breaking eggs to remove } \\
\text { whammy }\end{array}$ & 176 & 3.0 & $\begin{array}{l}\text { breaking eggs to remove } \\
\text { disaster }\end{array}$ & 214 & 3.1 \\
\hline 9 & belief in chance & 98 & 2.7 & fortunetelling, \&augury & 158 & 2.7 & $\begin{array}{l}\text { symbolic killing of } \\
\text { Omar(Omar koshoun) }\end{array}$ & 184 & 2.7 \\
\hline 10 & $\begin{array}{l}\text { opening the praying } \\
\text { book }\end{array}$ & 93 & 2.6 & sweeping at night & 140 & 2.4 & whammy & 176 & 2.6 \\
\hline 11 & $\begin{array}{l}\text { number } 13 \text { is unlucky / } \\
\text { the thirteenth of } \\
\text { Farvardin is unlucky }\end{array}$ & 73 & 2.0 & smoking wild rue & 137 & 2.3 & $\begin{array}{l}\text { to pick up the flag and } \\
\text { drumming in the } \\
\text { mourning ceremonies, } \\
\text { picking up the palm }\end{array}$ & 159 & 2.3 \\
\hline 12 & magic(mumbo jumbo) & 65 & 1.8 & magic \& charm & 133 & 2.3 & magic(mumbo jumbo) & 146 & 2.1 \\
\hline 13 & belief in jinni & 61 & 1.7 & number 13 is unlucky & 127 & 2.2 & grieving play & 136 & 2.0 \\
\hline 14 & ghost \& phantom & 59 & 1.6 & $\begin{array}{l}\text { say" in the name of God" } \\
\text { when pouring hot water }\end{array}$ & 76 & 1.3 & $\begin{array}{l}\text { the celebration of the last } \\
\text { Wednesday before } \\
\text { Nowrooz }\end{array}$ & 121 & 1.8 \\
\hline
\end{tabular}




\begin{tabular}{|c|c|c|c|c|c|c|c|c|c|}
\hline 15 & $\begin{array}{l}\text { belief in } 12 \text { religious } \\
\text { Imam, the } 12^{\text {th }} \text { Imam, } \\
\text { source of authority }\end{array}$ & 59 & 1.6 & tying grass & 75 & 1.3 & number 13 is unlucky / & 116 & 1.7 \\
\hline 16 & $\begin{array}{l}\text { auspicious or } \\
\text { inauspicious of some } \\
\text { people }\end{array}$ & 58 & 1.6 & $\begin{array}{l}\text { sitting near the foot of } \\
\text { the door leads to the } \\
\text { spouse's death }\end{array}$ & 60 & 1.0 & $\begin{array}{l}\text { tying grass is said to be } \\
\text { a good omen for single } \\
\text { people }\end{array}$ & 103 & 1.5 \\
\hline 17 & $\begin{array}{l}\text { If Saturday brings bad } \\
\text { luck, it goes until the } \\
\text { last day of the week }\end{array}$ & 58 & 1.6 & belief in jinni \& fairy & 57 & 1.0 & $\begin{array}{l}\text { necrolatry and their } \\
\text { ceremonies }\end{array}$ & 100 & 1.5 \\
\hline 18 & divining & 47 & 1.3 & $\begin{array}{l}\text { pouring tea pulp on the } \\
\text { tea is a sign of coming } \\
\text { guests }\end{array}$ & 55 & .9 & $\begin{array}{l}\text { not to spend money on } \\
\text { Saturday, don't visit a } \\
\text { doctor, if you do } \\
\text { anything at the beginning } \\
\text { of the week ,it is too bad }\end{array}$ & 97 & 1.4 \\
\hline 19 & $\begin{array}{l}\text { tying grass is said to be } \\
\text { a good omen for single } \\
\text { people }\end{array}$ & 47 & 1.3 & $\begin{array}{l}\text { if you do anything at the } \\
\text { beginning of the week, } \\
\text { you do the same until the } \\
\text { end of the week }\end{array}$ & 54 & .9 & $\begin{array}{l}\text { to hang tapestry in a } \\
\text { shrine }\end{array}$ & 95 & 1.4 \\
\hline 20 & praying or get pray & 43 & 1.2 & $\begin{array}{l}\text { falling sugar cube in the } \\
\text { tea means coming } \\
\text { guests }\end{array}$ & 54 & .9 & $\begin{array}{l}\text { salt, using stone to } \\
\text { remove whammy, using } \\
\text { salt for guest to go out }\end{array}$ & 80 & 1.2 \\
\hline & total & 2233 & 6108 & total & 3577 & 61 & total & 4437 & 6405 \\
\hline & Etc... & 1384 & 3802 & Etc... & 2288 & 39 & Etc... & 2448 & 3505 \\
\hline & total sum & 3617 & 100 & total sum & 5865 & 100 & total sum & 6885 & 100 \\
\hline
\end{tabular}

One of the Iranian's common beliefs is that when sneezing during any kind of activity or at the beginning of it, one must slow down and waits for a while. 10.4 percent of the respondents believe it is superstition. 10.4 percent of the respondents believe it is related to self- superstitious beliefs. This ratio shows the relationship between "sneezing" and "the necessity of being patient" as a cultural belief in Iran. It can be resolutely said that the first ten items for the individuals and parents are Iranian cultural beliefs in the way that if they do not believe in, they try to prevent an opposite action. As an example, if they do not believe in "sweeping at night" or "cutting nails at night" as an unlucky action, they try to prevent doing them at night.

One of the reasons in the importance of the data in table 4 and their acceptance as Iranian's common beliefs is the kind of open questions for the respondents in which they could answer freely. Therefore, the answers were various and a lot. The importance of the ratio and issues in the table is that 5.1 percent of respondents believe in "setting fire on wild rue" as a superstitious belief when the question is open but it reaches to 79.2 percent (in table 1) when the question is closed. In fact, the one or two percentage in table 4 is very important.

In relation to superstitious beliefs in the sub-province, it can be seen that some religious rituals or marriage ceremonies and some beliefs such as fortunetelling and augury are introduced as superstitious beliefs in the subprovince. Apart from these, the mentioned items for sub-province are related to group ceremonies and conventions. Some beliefs related to body organs, unluckiness of doing something in specific days, setting fire on wild rue and whammy are in the lower level. Religious beliefs in the self and parents are less classified in superstitious beliefs and they are related to popular religious ceremonies in the sub-province. The other reason can be related to the difference in the individuals' rethinking as the result of higher education and other social and background variables which give personal characteristic to their religiosity. Here, individuals rethink about some religious ceremonies in common religiosity domain and act selectively. Therefore, self-mutilation, to flagellate with a chain and to strike with a sword, picking up the flag, picking up the palm and the related items in mourning ceremonies are classified in superstitious beliefs although most clergymen are against them.

\section{Conclusion}

Many scholars, as discussed earlier, have mentioned to unstable, unsafe, and ambiguous conditions as of the main reasons for individuals' tendencies toward the superstitions. In fact, societies, in order to make the environment, outer conditions, and sense of control in individuals predictable has made up a group of beliefs to change the situations to more stable and calmer one in the shadow of these beliefs. 
Beliefs such as "being patient after sneezing", "considering some special activities ominous in some special days", and "smoking wild rue to remove evil eye" try to disambiguate the conditions and make the future more predictable for individuals. Additionally, believing in evil eye is a mechanism to give meaning to events and their negative results. Believing in evil eye convinces the individuals that he/she has no control over conditions, so they should not blame themselves for being faulty. This mechanism could have positive effect on individuals' mental health in stressful and disastrous situations.

Another case relating to the superstition is that of class changes in the society in major scale currently taking place in the society. New generations, generally, have inertia against the values and attitudes of the former generation; a part of this inertia is because of considering these beliefs, values and rituals as superstitious. Results of table 1 indicated that "education" is the most effective factor in individuals' tendencies toward the superstitions. Academic education has the most effective influence on individuals' attitudes and their re-socialization. Expanding the higher education in Iran as one of the modernization processes along with the new mass media has exposed Iranians to the waves of globalization. In such a situation, as Durkheim puts it, the society is passing from mechanical solidarity to organic solidarity during which the speed of value alteration has accelerated and individualism is taking over. The influence of strengthening of individualism is observable in individuals' avoidance from attending the rituals held and prevalent in their residences (table 4).

In recent decades in Iran, with the acceleration of modernization, the process of public values has also accelerated accordingly. It seems that Iranian society is trying to handle a new and appropriate combination of Tradition and Modernity. However this process of conflation has imposed lot of tensions and pressures onto the society. It is natural that with the changes available the public understanding of superstitions will change; and under the influence of individualism in society collective and traditional rituals will be weakened.

\section{References}

Al-Farahidi, Kh. A. (1988). Kitab al-Ayn. Edited by Mandi Al-Makhzami \& Ibrahim Al-Samirral. Beirut: al-'Alam ii al-Matbfeat. Al-Torayhi, F. M. (2001) Majma' Al-Bahrain wa Matla' Al-Nayerain. Tehran: Nashre Mostafavi.

Al-Zabidi , M. M. (2001). Taj Al 'Arus Min Jawhir Al-Qamus( 40 V.). Third Edition, Al-Kuwayt : Mạtbaat Hukumat Al-Kuwayt.

Amid, Hasan (2010). Amid Persian Dictionary. Tehran: Rahe Rosh Publication.

Barsky, A. J., Sainfort, R., Rogers, M. P., \& Borus, J. F. (2002). Nonspecific medication side effects and the nocebo phenomenon, Journal of the American Medical Association, 287(5), 622-627.

Becker, J. (1975). Superstitions in Sport. International Journal of Sport Psychology, 6, 148-152.

Beck, J., \& Forstmeier, W. (2007). Superstition and belief as inevitable by-products of an adaptive learning strategy. Human Nature, 18(1), 35-46.

Bernardin, A. (2004). The tea leaves of sports talk. Skeptic, 11(2), 54-59.

Bleak, J. L., \& Frederick, C. M. (1998). Superstitions behavior in sport: Levels of effectiveness and determinants of use in three collegiate sports. Journal of Sport Behavior, 21(1), 1-15.

Blum, S. H., \& Blum, L. H. (1974). Do's and don'ts: An informal study of some prevailing superstitions. Psychological Reports, 35, 567571.

Campbell, C. (1996). Half-belief and the paradox of ritual instrumental activism: A theory of modern superstition. British Journal of Sociology, 47(1), 151-166.

Case, T. I., Fitness, J., Cairns, D. R., \& Stevenson, R. J. (2004). Coping with uncertainty: Superstitious strategies and secondary control. Journal of Applied Social Psychology, 34(4), 848-871.

Douglas, M. (1966). Purity and danger. London: Routledge and Kegan paul.

Dunleavy, A. O., \& Miracle, A. W. (1981). Sport: an experimental setting for the development of a theory of ritual In Play as context. Edited by A. T. Cheska. West Point, New York: Leisure Press.

Durkheim, E. (1912/1965). The Elementary Forms of Religious Life. New York: Free Press.

Emme, E. E. (1940). Modification and origin of certain beliefs in superstition among college students. Journal of Psychology, 10, 279291.

Encyclopedia of Britannica (2008). Chicago: Encyclopaedia Britannica Publication.

Frost, R. O., Krause, M. S., McMahon, M. J., Peppe, J., Evans, M., McPhee, A. E., \& Holden, M. (1993). Compulsivity and Superstitiousness. Behaviour Research and Therapy, 31, 423-425.

Gallup, G. H., \& Newport, F. (1990). Belief in the psychic and paranormal widespread among Americans. Gallup New Service, 55, 1-7.

Gmelch, G., \& Felson, R. (1980). Can a Lucky charm get you through organic chemistry? Psychology Today, 14, Dec., 75-78.

Griffiths M. D., \& Bingham, C. (2005). A study of superstitious beliefs among bingo players. Journal of Gambling Issues, 13.

Jahoda, G. (1969). The psychology of superstition. London: Allan Lane, the Penguin Press.

Jarvis, P. (1980). Towards a sociological understanding of superstition. Social Compass, 27(2), 285-295.

Hansen, B. (1986). The Complementarity of Science and Magic Before the Scientific Revolution. The American Scientist, 74(2), $128-136$. 
Hunt, E., \& Short, S. (2006). Collegiate athletes' perception of adverse ankle taping: A qualitative analysis. Journal of Sport Rehabilitation, 15(4), 280-298.

Keinan, G. (1994). Effects of stress and tolerance of ambiguity on magical thinking. Journal of Personality and Social Psychology, 67(1), 48-55.

Langer, E. J. (1975). The illusion of control. Journal of Personality and Social Psychology, 32(2), 311-328.

Langer, E. J., \& Roth, J. (1975). Heads I win, tails it's chance: The illusion of control as a function of the sequence of outcomes in a purely chance task. Journal of Personality and Social Psychology, 32, 951-955.

Laurin, K., Kay, A. C., \& Moscovitch, D. A. (2008). On the belief in God: Towards an Understanding of the emotional substrates of compensatory control. Journal of Experimental Social Psychology, 44, 1559-1562.

Malinowski, B. (1948). Magic, science, and religion and other essays. Glencoe, Illinois: The Free Press.

McCartney, E. S. (1952). The Superstition about literal and figurative separation of persons. Classical Journal, 48(2), Nov. 74.

McGregor, I. (2006a). Offensive defensiveness: Toward an integrative neuroscience of compensatory zeal after mortality salience, personal uncertainty, and other poignant threats. Psychological Inquiry, 17, 299-308.

McGregor, I. (2006b). Zeal appeal: The allure of moral extremes. Basic and Applied Social Psychology, 28, 343-348.

McGregor, I., Haji, R., Nash, K. A., \& Taper. R. (2008) Religious zeal and the uncertain self. Basic and Applied Social Psychology, 30, 183-188.

McGregor, I., Zanna, M. P., Holmes, J. G., \& Spencer, S. J. (2001). Compensatory conviction in the face of personal uncertainty: Going to extremes and being oneself. Journal of Personality and Social Psychology, 80, 427-488.

Moein, M. (1999). Moein's Persian Dictionary. Vol. 4, Tehran: Amir Kabir Publication

Neil, G. (1982). Demystifying sport superstitions. International Review of Sport Sociology, 17 (1), 99-124.

Otis, L. P., \& Alcock, J. E. (1982). Factors affecting extraordinary belief. The Journal of Social Psychology, 118, 77-85.

Oxford English Dictionary (2012). Oxford; New York: Oxford University Press.

Rudski, J. (2004). The illusion of control, superstitious belief, and optimism. Current Psychology, 22, 306-315.

Rudski, J. \& Edwards, A. (2007). Malinowski goes to college: Factors influencing student's use of ritual and superstition. The Journal of General Psychology, 134(4), 389-403.

Rudski, J., Lischner, M. I., \& Albert, L. (1999). Superstitious rule generation is effected by probability and type of outcome. Psychological Record, 49, 245-260.

Peltzer k. (2002). Magical thinking and paranormal beliefs among secondary and university students in South Africa. Personality and individual Differences, Volume 35, Issue 6, Pp. 1419-1426.

Perkins, M. (1996). Visions of the future - Almanacs, time, and cultural change 1775-1870. Oxford: Calendorn Press.

Perkins, M. (2000). The reform of time: magic and modernity. London, VA: Pluto Press.

Pronin, E., Rodriguez, S., Wegner, D. M., \& McCarthy, K. (2006) Everyday magical powers: The role of apparent mental causation in the overestimation of personal influence. Journal of Personality and Social Psychology, 91(2), 218-231.

Shartuni al-Khuri , S.(1992). Aqrab al-mawarid fī fusuh al-'Arabiyah wa-al-shawarid (2 v.). Bayrut : Maktabat Lubnan Nashirun

Skinner, B. F. (1948). "Superstition" in the pigeon. Journal of Experimental Psychology, 38, 168-172.

Statistical Center of Iran (2006). Iranian population and Housing Census. Final Report.

Taylor, S. E. (1983) Adjustment to threatening events: A theory of cognitive adaption. American Psychologist, 38, 1161-1173.

Tobacyk, J., \& Milford, G. (1983). Belief in paranormal phenomena: Assessment instrument development and implications for personality functioning. Journal of Personality and Social Psychology, 44, 1029-1037.

Torgler, B. (2007). Determinants of superstition. Journal of Socio-Economics, 36(5), 713-733.

Vyse, S. A. (1997). Believing in magic: The psychology of superstition. Oxford University Press.

Webster's Third new international dictionary- unabridged ( 1986). by Philip Babcock Gove; Springfield, Mass. : Merriam-Webster Publication.

Weiner, E. (2008). The Geography of Bills. New York, NY: Hatchette Book Group.

Wagner, G. A., \& Morris, E. K. (1987) "Superstitious" behavior in children. The Psychology Record, 37, 471-488.

Womack, M. (1992). Why Athletes need ritual: A Study of Magic among professional athletes. In S. J. Hoffman (Ed.), sport and religion (pp. 191-202). Champaign, IL: Human Kinetics.

Zebb B. J., \& Moore. M. C. (2003). Superstitiousness and perceived anxiety control as predictors of psychological distress. Journal of Anxiety Disorders, 17(1), pp. 115-130. 